\title{
Reexamining Povarov Reaction's Scope and Limitation in the Generation of HCV-NS4A Peptidomimetics
}

\author{
Maan T. Khayat $\mathbb{D}^{1},{ }^{1}$ Abdelsattar M. Omar $\mathbb{D}^{1,2,3}$ Mahmoud A. Elfaky ${ }^{\mathbb{D}},{ }^{2,4}$ \\ Yosra A. Muhammad $\mathbb{D},{ }^{1,2}$ Elaf A. Felemban $\mathbb{D}^{1},{ }^{1}$ Khalid M. El-Say $\mathbb{D}^{1},{ }^{5}$ \\ and Moustafa E. El-Araby $\mathbb{D}^{1,2}$ \\ ${ }^{1}$ Department of Pharmaceutical Chemistry, Faculty of Pharmacy, King Abdulaziz University, Jeddah 21589, Saudi Arabia \\ ${ }^{2}$ Center for Artificial Intelligence in Precision Medicines, King Abdulaziz University, Jeddah 21589, Saudi Arabia \\ ${ }^{3}$ Faculty of Pharmacy, Department of Pharmaceutical Chemistry, Al-Azhar University, Nasr City, Cairo, Egypt \\ ${ }^{4}$ Department of Natural Products and Alternative Medicine, Faculty of Pharmacy, King Abdulaziz University, \\ Jeddah 21589, Saudi Arabia \\ ${ }^{5}$ Department of Pharmaceutics, Faculty of Pharmacy, King Abdulaziz University, Jeddah 21589, Saudi Arabia
}

Correspondence should be addressed to Moustafa E. El-Araby; madaoud@kau.edu.sa

Received 1 December 2021; Revised 29 December 2021; Accepted 5 January 2022; Published 10 February 2022

Academic Editor: Jin Xie

Copyright (c) 2022 Maan T. Khayat et al. This is an open access article distributed under the Creative Commons Attribution License, which permits unrestricted use, distribution, and reproduction in any medium, provided the original work is properly cited.

\begin{abstract}
Chronic Hepatitis $\mathrm{C}$ is a global health threat and a silent killer. Regardless of the profound progress in preventing and treating this disease, research continues to discover new direct antiviral agents (DAAs), especially against novel targets. Our research has been directed to leverage the NS4A binding site to develop peptidomimetic inhibitors of the hepatitis C virus (HCV) NS3 protease. In previous reports, we could provide evidence of tunability of this site by peptide and nonpeptide NS3/4A inhibitors. In this report, we used structure-based techniques to design 1,2,3,4-tetrahydro-1,7-naphthyridine derivative as NS4A core mimics that cover the region between residues Ile- $25^{\prime}$ to Arg- $28^{\prime}$. The synthetic plan featured the Povarov reaction as an efficient strategy to construct the 1,7-naphthyridine core. Although this reaction has been reported in many literatures, critical assessments for its scope and limitations are scarce. In our work, we found that Povarov was extremely sensitive to alkene and aldehyde reactants. Moreover, using pyridine amines was not as successful as anilines. The most striking results were the lack of stability of compounds during purification and storage. The four compounds that survived the stability problems (1a-1d) did not show significant binding potency with NS3, because their structures were too simple to resemble the originally planned compounds.
\end{abstract}

\section{Introduction}

Hepatitis $\mathrm{C}$ virus (HCV) is a silent killer that starts with mild or even no symptoms, but in many cases, it advances to a life-long illness [1]. The HCV, when activated, attacks liver cells through its E2-envelop protein, maneuvers to penetrate the cell membrane and proceeds to disrupt cellular mechanisms, controls genetic expressions, and leverages cellular machinery to replicate $[2,3]$. Moreover, HCV can evade the innate immunity challenges and becomes a persistent infection [4]. Consequently, the liver starts to enlarge and develop inflammatory responses followed by necrosis and extensive damage of hepatic tissues leading to cirrhosis that ends with liver cancer [5]. In its 2019 report, the World Health Organization (WHO) estimated that more than 70 million people are infected with HCV regardless of the great progress in the control and treatment since 2013 [6].

The recent success of newly discovered direct antiviral agents (DAAs) led to a significant decline in HCV-related deaths concomitant to an increase in survival and recovery rate of patients suffering from the high viral count in their blood [7]. The approved DAAs up until now are directed to three targets: substrate-site inhibitor of NS3/4A protease, NS5A, and NS5B [8] (Figure 1). We have been interested in exploring NS4A as a target $[9,10]$, aiming to add more drugs to the DAA arsenal that may curb the increasingly emerging 


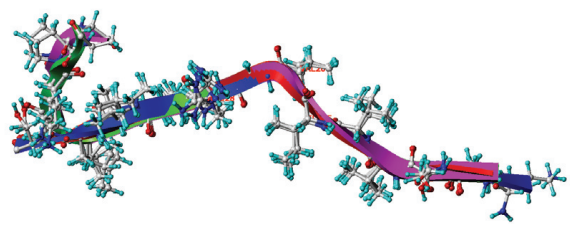

(a)

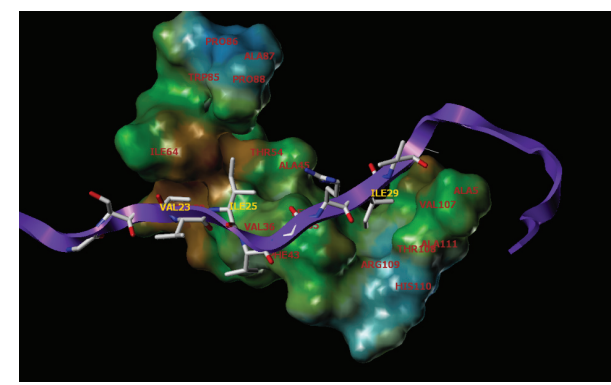

(b)

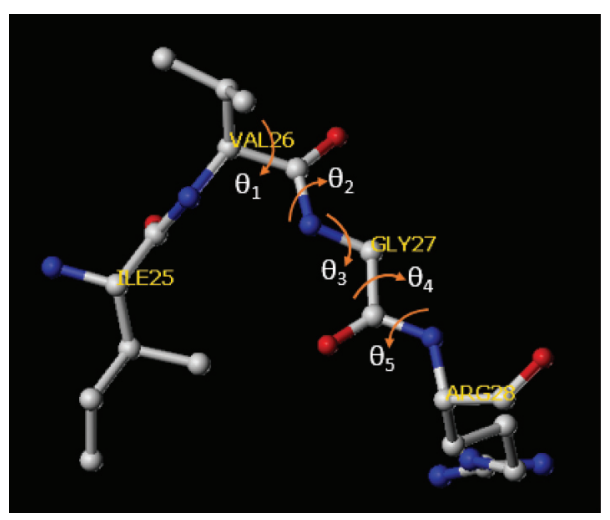

(c)

Figure 1: Conserved conformation of NS4A peptide in bound form with NS3 protease domain. (a) Examples of bound NS4A downloaded from the PDB website (rcsb.org) and illustrated as follows: 1A1R (Green), 2OC1 (magenta), 3OYP (Red), and 4U01 (Blue). (b) The binding of NS4A (PDB Code: 1NS3) with apoprotein residues guided our peptidomimetics design. (c) Dihedral angles $\theta_{n}$ of the bound NS4A's planar region (PDB Code: 1NS3). Numerical values of $\theta_{1}$ to $\theta_{5}$ are listed in Table 1.

resistance against available DAAs. Another important reason for targeting NS4A is that this 54-mer amino acid peptide is a common factor, albeit not structurally or functionally conserved, among all Flaviviridae family. This family of viruses comprises highly pathogenic viruses such as Zika, Dengue, and West Nile fever. In HCV, this small peptide is a multipurpose tool for $\mathrm{HCV}$ maturation and replication. It plays irreplaceable roles in activating the NS3 protein (both protease and RNA helicase functions), curbing host-cell immunological responses, and integrating the NS3 into the endoplasmic reticulum.

X-ray structures of NS3 complexed with NS4A revealed that the binding of the NS4A peptide initiates ordering of the $\mathrm{N}$-terminal 28 residues of the NS3 protease into a $\beta$-strand and an $\alpha$-helix $[11,12]$. It also causes local rearrangements, which are important for a catalytically favorable conformation at the active site. According to serine and alanine scanning studies, the hydrophobic residues Val-23', Ile-25', Gly-27', Ile-29', and Leu- $31^{\prime}$ were found to be the most important to the enzyme activation, while the Arg- $28^{\prime}$ was controversial [13, 14]. As shown in Figure 1, the NS4A $21^{\prime}-34^{\prime}$ peptide displays a brief bulge at Ile-25' and Val-26' extended conformation. It forms main-chain hydrogen bonds with the $A_{0}$ and $A_{1}$ strands of the protease in an antiparallel fashion (Figure 2). Another important conformational feature is that the kinky area of the bound $\mathrm{NS} \mathrm{A}_{21^{\prime}-34^{\prime}}$ is almost planar, giving a good opportunity to design some cyclic aromatic structures that mimic this area and bind in the same manner, the NS3 protease. This conformation is conserved in all HCV NS3/4A protease crystal structures reported until now $[9,10]$.

A few previous reports that investigated synthetic peptide variants of NS4A N-terminal provided strong grounds for leveraging this new target since some of these peptides could inhibit the function of NS3 protease in vitro [10]. Moreover, we succeeded in introducing $1 \mathrm{H}$-imidazole-2,5-dicarboxamide derivatives as peptidomimetic that competed with NS4A and replaced it in binding assays with NS3 protease [9]. The imidazole, however, is a 5-membered monocyclic ring that mimicked the amide bond between Val-26' and Gly-27'. Meanwhile, the flat kink of NS4A encompasses five bonds in this area (Figures 1 and 2 and Table 1).

To increase the binding potency of the heterocyclic nonpeptide mimics of NS4A, a bicyclic structure involving more bonds in this area was envisaged, because rigidification is an effective strategy to increase binding potency eliminating entropy factors of bond rotations.

\section{Results and Discussion}

2.1. Rationale and Design. Figure 2(c) represents a promising bicyclic nucleus that established the same interactions of the mimicked planar region of the NS4A. The NH at the position of the THN nucleus could establish hydrogen bonds with the carbonyl of Ile-36. The carbonyl at position 4 of THN is ideal for replacing the carbonyl Val-26'. The isopropyl sidechain of Val-26' was ignored for simplification 


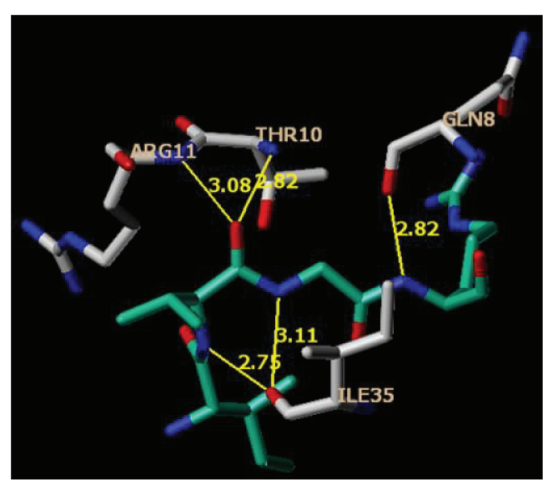

(a)

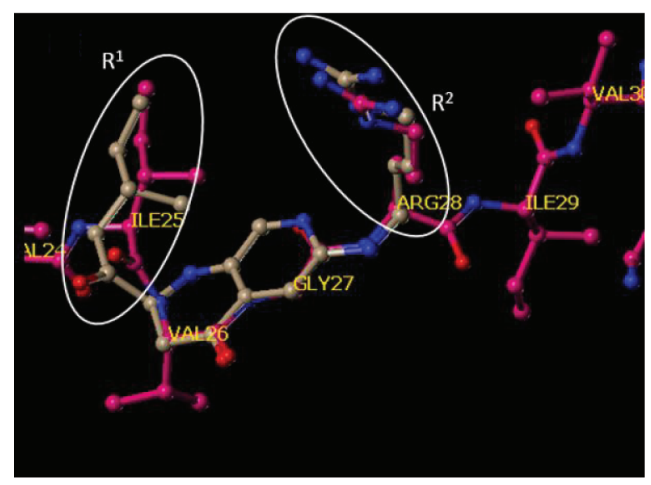

(b)

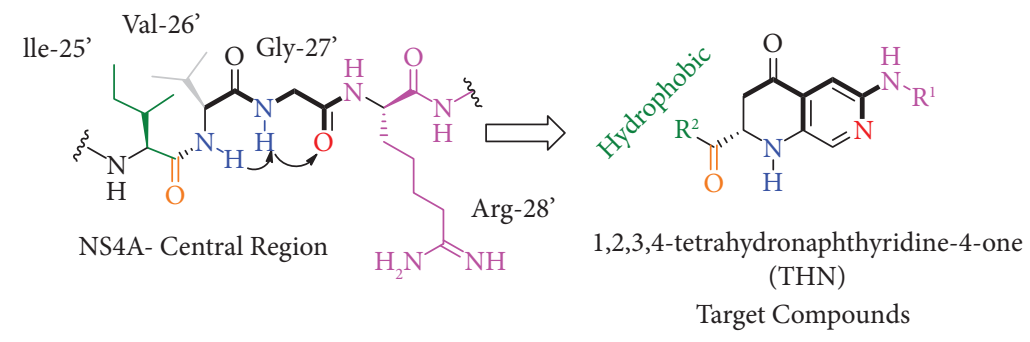

(c)

FIgURe 2: Design of THN scaffold as potential NS4A peptidomimetic. (a) Binding features of the NS4A with amino acids in the NS3. Important hydrogen bonding interactions are shown in yellow lines. H-bond lengths are shown in $\AA$ length units, and they were measured between heavy atoms. (b) Alignment of the designed core THN (golden color) with the NS4A core region bound to NS3. Circles illustrate good fit of $\mathrm{R}^{1}$ and $\mathrm{R}^{2}$ with the cofactor side chains. (c) Sketch of the designing method of THN to mimic the core part of NS4A. The bold bonds highlight the planar area in the kink region of NS4A that was transformed to a bicyclic structure in the designed peptidomimetic THN scaffold. Similarly, colored heteroatoms represent equivalent replacements.

TABLE 1: Dihedral angles of the core part of bound NS4A (PDB Code: 1 NS3).

\begin{tabular}{lcc}
\hline Torsion & Actual & Deviation from Plane \\
\hline$\theta_{1}$ & 13.9 & +13.9 (eclipsed cis) \\
$\theta_{2}$ & 179.4 & -0.6 \\
$\theta_{3}$ & 184.6 & +4.6 \\
$\theta_{4}$ & 191.6 & +11.6 \\
$\theta_{5}$ & 184.3 & +4.3 \\
\hline
\end{tabular}

purposes, because it was considered ineffective in the NS4A function [13]. The aromatic pyridine ring contains nitrogen, which acted as a hydrogen bond acceptor as a carbonyl replacement at groups $\mathrm{R}^{1}$ aligning with Ile- $25^{\prime}$ side chain; therefore, groups at this side chain are expected to be hydrophobic (Figure 1(b)). This pocket is composed of hydrophobic residues Trp-85, Pro-86, Ala-87, and Pro-88. It was in our focus as a good opportunity for obtaining tight binding peptidomimetics by making a library of compounds with $\mathrm{R}^{2}=$ hydrophobic groups of different sizes and branching (Figure 2(c)).

2.2. Synthetic Plan of Target Compounds. The target scaffold (THN derivatives, $\mathrm{X}=\mathrm{N}$ ) is an aza variant of 1,2,3,4-tetrahydroquinolines $(\mathrm{X}=\mathrm{CH})$, a nucleus commonly accessible via Povarov reaction (Scheme 1). The Povarov reaction (aka aza Diels-Alder or imino Diels-Alder) is a three-component reaction between an aromatic amine, an aldehyde, and an alkene in the presence of a Lewis or a Brønsted acid catalyst
$[15,16]$. Povarov chemistry has been extensively utilized to construct several heterocyclic structures especially pyridinefused heterocycles [17]. Regardless of the fact that Povarov first reported the inverse electron demand $4+2$ cycloaddition between a Schiff base (formed in situ) and electronrich alkene in the 1960s, the interest in this reaction increased vastly only in the past decade [18]. The most common and earliest heterocyclic system that has been efficiently prepared using the Povarov reaction is $1,2,3,4-$ tetrahydroquinoline [19-21].

Planning for the synthesis of the final compounds, it was decided to start with suitably substituted arylamine $\mathbf{1}$ and react it with aldehyde $\mathbf{2}$ and the protected vinyl alcohol $\mathbf{3}$ to obtain the 1,7-naphtyridine 4. Having the core nucleus of the target compounds assembled, the crucial intermediate 5 (a deprotection product of 4) would be completed to the designed target compounds. Unfortunately, we encountered some difficulties in the early stages of the synthesis of the Povarov reaction step, as yields of Povarov products by using pyridyl amines were low. In some cases, the intended product was not observed in LC/ MS analysis. Therefore, we thought of using aniline as an arylamine component that furnishes 1,2,3,4-tetrahydroquinoline (THQ) variants of the target scaffold (THN). THQ is a simpler structure, and it is more studied in previous reports [22]. Additionally, the THQ $(\mathrm{X}=\mathrm{CH})$ scaffold should be useful to investigate the utility of Povarov chemistry in our synthetic plans and study the structure-activity relationships. Results of the reactions of aniline with a variety of aldehydes and alkenes are shown in Scheme 2 and Table 2. 


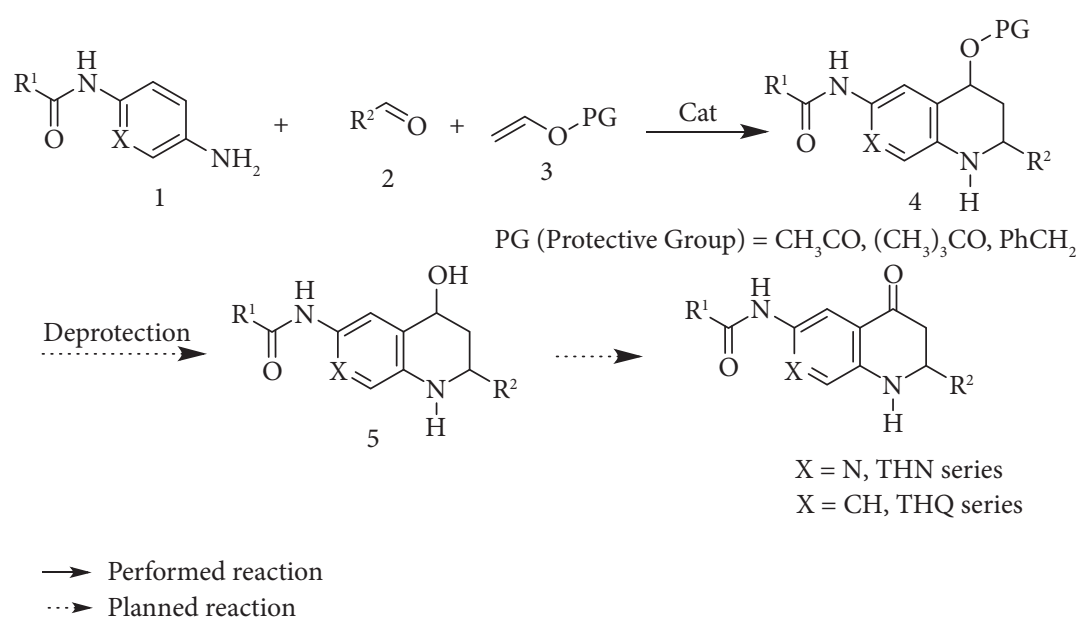

Scheme 1: Putative Scheme for synthesis of scaffold 2 compounds. Cat = Lewis acid catalyst, THN = 1,2,3,4-tetrahydro-1,7-naphthyridine, THQ = 1,2,3,4-tetrahydroquinoline.

2.3. Limitations of the Alkene and the Aldehyde Components in the Povarov Reaction. As illustrated in Scheme 2 and Table 2, the simplest arylamine, aniline (1a), was successfully reacted with benzaldehyde (2a) and acyclic vinylic ethers (3a-c) (Compounds 4a-c, Entries 1-5). This success was expected, and it agrees with results previously reported elsewhere [22]. According to the design described above, the non-alkene portion acts as a temporary protective group (PG). It should be removed to obtain alcohol (intermediate 5) followed by oxidation to provide the ketone group in the target compound. Accordingly, we used the alkene component as vinyl ester, such as vinyl acetate or vinyl pivalate. We observed that the reaction stops at the stage of the Schiff base intermediate, as monitored by LC/MS. The failure of the Povarov reaction with vinyl esters confirms the ultra-sensitivity of this reaction to the electronic character of the alkene component. Our observation agrees with reports by Isambert and coworkers who reported that vinyl acetate does not advance the Povarov intermediate to cyclization via Friedel-Crafts mechanism as a termination step [23]. Therefore, we decided to focus on the more suitable vinylic ethers. In particular, benzyl vinyl ether (BVE, 3d) has a removable group (considered as protective group, $\mathrm{PG}$ ), but it was too expensive to consume in the chemistry development and optimization. Consequently, we started efforts to examine the utility of the Povarov chemistry in our synthesis using affordable alkenes such as ethyl vinyl ether (EVE, 3a), 3,4-dihydro-4H-pyran. (DHP, 2b), and 2,3-dihydrofuran (DHF, 2c). EVE (3a) was of special importance, because it is similar to BVE. The cyclic ethers DHF and DHP were used as positive references, because they are the most common alkenes used in the Povarov chemistry literature [19-21].

2.4. The Behavior of Aromatic Aldehydes, Aliphatic Aldehydes, and 2-Oxoaldehydes. We reacted 3a-c with aniline (1a) and a set of five aldehydes (2a-e) encompassing two aromatic aldehydes (2a and $\mathbf{2 c}$ ), an aliphatic aldehyde (2b), and two 2-oxoaldehydes (2d-e). The product formation was easier for aromatic aldehydes (2a and 2c) (Entries 1-7,
Products 4a-d and Entries 12-17, Products 4g-i), as compared to the aliphatic 1-butanal (2b) (Entries 8-11). It was noticed that some 1-butanal reactions (Entries 9-11) gave the same side product with mass at $m / z 202$ that repeatedly appeared along with the product peak (Entries 9-11). This side product was not a Schiff base of aniline with 1-butanal (M.Wt. = 148). From LC/MS data, we speculated that it is the Schiff base of 4-alkylated aniline (a Friedel-Crafts product) (Scheme 3).

Ethyl glyoxylate (EtGlx, 2d) is an aldehyde with an ester tethering at $\mathrm{C} 2\left(\mathrm{R}^{3}\right)$ furnished Povarov products $\mathbf{4 j}$ and $\mathbf{4 k}$ when reacting with the alkenes 3a,d (Entries 18-21). The use of phenylglyoxal (PhGlx, 2e) as the aldehyde component in this reaction with vinyl esters (as an alkene component) provided an extremely different reaction pathway that was described elsewhere [24]. However, PhGlx could react with electron-rich alkenes such as $\mathbf{3 a - c}$ as detected by LC/MS (Entries 22-28) to give the derivatives $4 \mathbf{l - 4 m}$. Both 2-oxo aldehydes (EtGlx and PhGlx) are important for our targeted NS4A peptidomimetics as illustrated in Figures 2(b) and 2(c) for the design of target THN derivatives. We became particularly more optimistic when the Povarov reaction of aniline with EtGlx (2d) and BVE (3d) provided the MS peak of the product $4 \mathbf{k}$, which featured a benzyl protecting group for the oxy group at position $\mathrm{C} 4$ of the THQ nucleus. In addition, $\mathbf{4 k}$ contains an ester group at position $\mathrm{C} 2$, which can be later manipulated into interesting screenable set of compounds for their inhibition of the target HCV-NS3. Accordingly, we decided to investigate the Povarov reaction with arylamine monomers (other than aniline 1a) that contain a protected amine substituent aiming to move forward with the synthetic plan illustrated in Scheme 1 (See Scheme 4 below).

2.5. Cerium IV Ammonium Nitrate (CAN) and Montmorillonite KSF (M-KSF) Are Suitable Catalysts for the Povarov Reaction. From a long list of Lewis Acid catalysts reported in the literature [22], we selected the inexpensive cerium IV ammonium nitrate (CAN) and Montmorillonite KSF (M- 


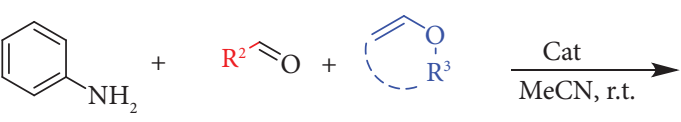

la $\quad 2 a-e \quad 3 a-d$<smiles>CCOCCOC1CC(c2ccccc2)Nc2ccccc21</smiles>

\section{Aldehydes}<smiles>CCCC=O</smiles><smiles>[CH]=Cc1ccco1</smiles>

2b, 1-Butanal 2c, Furfural<smiles>O=CC=O</smiles><smiles>O=CC(=O)c1ccccc1</smiles><smiles>[R]C1Nc2ccccc2C([R])C1CI</smiles>

$4 a-n$
$4 a$<smiles>c1ccc(C2Nc3ccccc3C3OCCCC23)cc1</smiles>

$4 \mathrm{~b}$<smiles>c1ccc(C2Nc3ccccc3C3OCCC23)cc1</smiles>

$4 \mathrm{c}$<smiles>c1ccc(COC2CC(c3ccccc3)Nc3ccccc32)cc1</smiles>

$4 \mathrm{~d}$<smiles>CCCC1Nc2ccccc2C2OCCCC12</smiles>

$4 \mathrm{e}$<smiles>CCCC1CC(OCC)c2ccccc2NC1COC1CC(C(=O)OCC)Nc2ccccc21</smiles>

$4 \mathrm{k}$<smiles>c1coc(C2Nc3ccccc3C3OCCCC23)c1</smiles>

$4 \mathrm{~g}$<smiles>CCOC1CC(C(=O)c2ccccc2)Nc2ccccc21</smiles>

41<smiles>c1coc(C2Nc3ccccc3C3OCCC23)c1</smiles>

$4 \mathrm{~h}$<smiles>O=C(c1ccccc1)C1Nc2ccccc2C2OCCCC12</smiles>

$4 \mathrm{~m}$<smiles>c1ccc(COC2CC(c3ccco3)Nc3ccccc32)cc1</smiles>

$4 \mathrm{i}$<smiles>CCOC(=O)C1CC(OCC)c2ccccc2N1</smiles>

$4 \mathrm{j}$

Scheme 2: Povarov reactions using aniline (1a), aldehydes (2a-e), and alkenes (3a-f) using a catalyst (Cat). $R^{1}$ is absent, because $R^{1}$ is assigned to arylamine monomers as mentioned in Scheme 1. In this scheme, only aniline was used as an arylamine.

KSF) to try at this exploratory and chemistry development stage. CAN reaction setup is simple, does not require strict conditions (in terms of moisture and air control), and indeed its Povarov reported yields are high. The montmorillonite clays are green catalysts of natural origin that can be easily removed by filtration [25]. Results in Table 1 show that both catalysts provided similar yields depending on the reactants rather than the catalyst type.

2.6. Attempts to Broaden the Scope of the Povarov Reaction to Synthesize Target Compounds. To move a step forward towards the synthesis of a screenable library of target compounds, we carried out Povarov reactions using monoBoc-1,4-phenylenediamine (1b) and 5-amino-2-(N-Bocamino)-pyridine (1c) with a set of aldehydes (2a-c, 2f-g) along with the previously used activated alkenes 3a-d (Scheme 4, Table 3). The arylamines $\mathbf{1 b}-\mathbf{c}$ carry a Boc-protected amine that could be later diversified by alkylation or acylation $\left(\mathrm{R}^{1}-\mathrm{NH}\right.$ in Scheme 1$)$.
To broaden the scope, we included a set of aldehydes encompassing benzaldehyde (2a) as a reference, two heteroaromatic aldehydes (2c, $\mathbf{2 g}$ ), two aliphatic aldehydes (2b, $\mathbf{2 f}$ ), and a 2-oxoaldehyde (2d). The alkene component included the previously used monomers 3a-d. Unfortunately, aniline 1a was overall a better amine in the Povarov reaction than its variants $\mathbf{1 b}$ and $\mathbf{1} \mathbf{c}$. The phenyl variant $\mathbf{1} \mathbf{b}$ provided the desired products $\mathbf{5 a - c}$, albeit in low yields. The more important pyridylamine 1c could also show some positive results but failed to give the desired product MS peak in reactions with $\mathbf{2 a / 3 b}$ (Entries 35-38) or with $\mathbf{2} \mathbf{c} / \mathbf{3 b}$ (Entry 39), regardless of our attempts to push the reaction by increasing the amount of the catalyst (Entries 37-38). However, 1c could provide the required product MS peak with several combinations of reactants (Entries 40-53, Products $\mathbf{5 f - m}$ ). It was noticed that CAN catalyst performed better than the M-KSF clay with this particular amine (2c). For instance, the product was detected in several cases when CAN was used as catalyst such as Entries 40, 48, 50, and 52 (Products 5g and 5k-m) but not M-KSF (Entries 42, 49, 51 


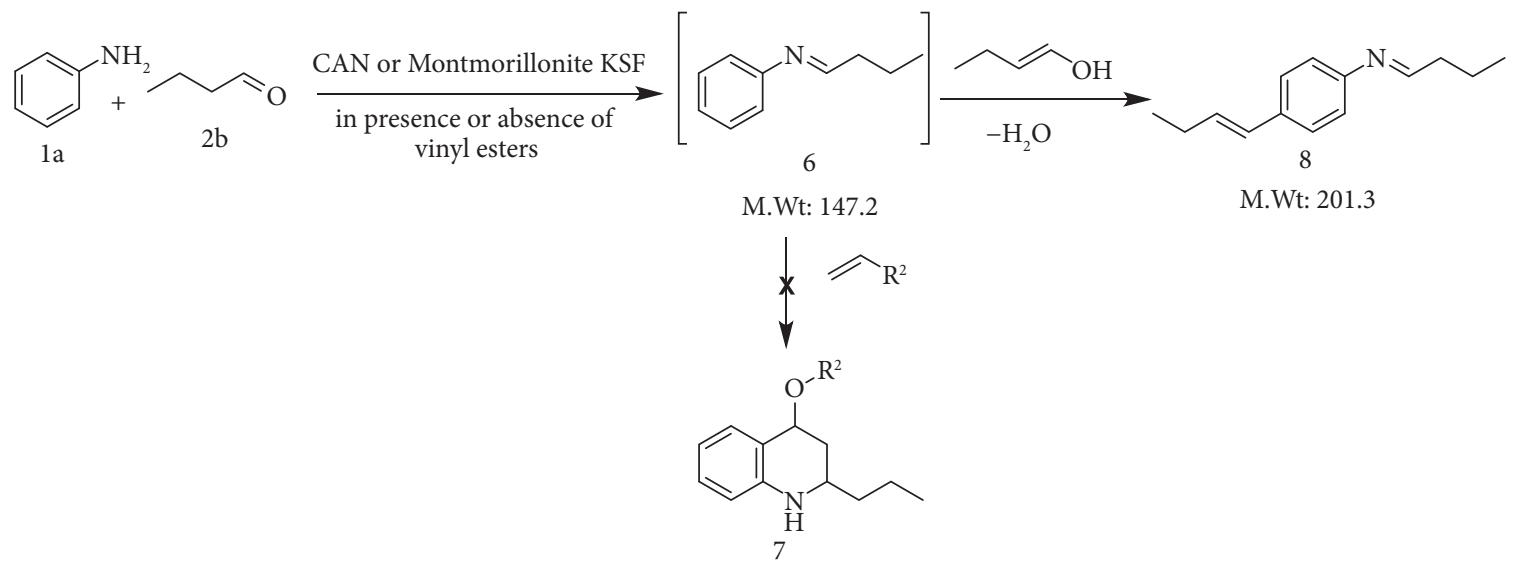

Scheme 3: Formation of side product by reaction of butanal and aniline under Povarov conditions.

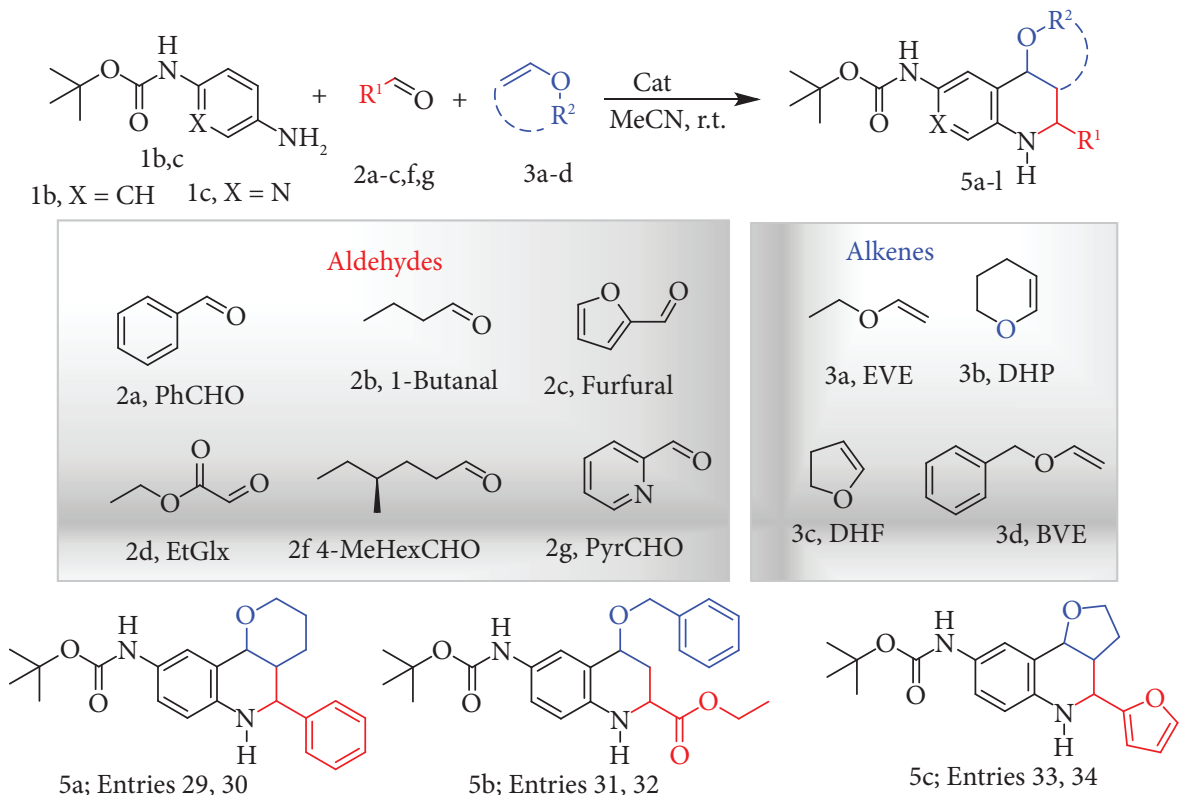<smiles>CC(C)(C)OC(=O)Nc1cc2c(cn1)N([14CH3])C(c1ccccc1)C1CCCOC21</smiles>

5d; Entries 35-38<smiles>CC(C)(C)OC(=O)Nc1cc2c(cn1)NC(c1ccco1)C1CCCOC21</smiles><smiles>CC(C)(C)OC(=O)Nc1cc2c(cn1)NC(c1ccco1)C1CCOC21</smiles>

5h; Entriy 44<smiles>CCC(C)CCC1Nc2cnc(NC(=O)OC(C)(C)C)cc2C2OCCC12</smiles>
5j; Entry 47<smiles>CC(C)(C)OC(=O)Nc1cc2c(cn1)NC(c1ccccn1)C1CCOC21</smiles>

5k; Entries 48-49<smiles>CCCC1CC(OCC)c2cc(NC(=O)OC(C)(C)C)ncc2N1</smiles>

5f; Entries 40-42<smiles>CCC(C)CCC1CC(OCc2ccccc2)c2cc(NC(=O)OC(C)(C)C)ncc2N1</smiles>
5i; Entries 45-46<smiles>CC(C)(C)OC(=O)Nc1cc2c(cn1)NC(c1ccccn1)C1CCCOC21</smiles>

51; Entries 50-51<smiles>CC(C)(C)OC(=O)Nc1cc2c(cn1)N(C(C)(C)C)C(c1ccccn1)CC2OCc1ccccc1</smiles>

Scheme 4: Povarov reactions using mono-Boc-1,4-phenylenediamine (1b) and 5-amino-2-(N-Boc-amino)-pyridine (1c), aldehydes (2a-d \& 2f-g), and alkenes (3a-c \& 3f) using CAN or M-KSF as catalysts (Cat.). 
TABle 2: Results of Povarov reactions are shown in Scheme 2.

\begin{tabular}{|c|c|c|c|}
\hline Entry & Product & Catalyst & Product $\%$ \\
\hline 1 & $4 \mathrm{a}$ & CAN & $59 \%$ \\
\hline 2 & \multirow{2}{*}{$4 \mathrm{~b}$} & CAN & $18 \%$ \\
\hline 3 & & M-KSF & $62 \%$ \\
\hline 4 & \multirow{2}{*}{$4 c$} & CAN & $80 \%$ \\
\hline 5 & & M-KSF & $68 \%$ \\
\hline 6 & \multirow{2}{*}{$4 \mathrm{~d}$} & CAN & $50 \%$ \\
\hline 7 & & M-KSF & $48 \%$ \\
\hline 8 & \multirow{2}{*}{$4 \mathrm{e}$} & CAN & ND \\
\hline 9 & & M-KSF & $\mathrm{ND}, 43 \%$ of $[\mathrm{M}+\mathrm{H}]^{+} 202$ \\
\hline 10 & \multirow{2}{*}{$4 \mathrm{f}$} & CAN & $32 \%$ product and $15 \%$ of $[\mathrm{M}+\mathrm{H}]^{+} 202$ \\
\hline 11 & & M-KSF & $22 \%$ product and $30 \%$ of $[\mathrm{M}+\mathrm{H}]^{+} 202$ \\
\hline 12 & \multirow{2}{*}{$4 \mathrm{~g}$} & CAN & $80 \%$ \\
\hline 13 & & M-KSF & $20 \%$ \\
\hline 14 & \multirow{2}{*}{$4 \mathrm{~h}$} & CAN & $50 \%$ \\
\hline 15 & & M-KSF & $48 \%$ \\
\hline 16 & \multirow{2}{*}{$4 \mathrm{i}$} & CAN & $40 \%$ \\
\hline 17 & & M-KSF & $52 \%$ \\
\hline 18 & \multirow{2}{*}{$4 j$} & CAN & $38 \%$ \\
\hline 19 & & M-KSF & $11 \%$ \\
\hline 20 & \multirow{2}{*}{$4 k$} & CAN & $32 \%$ \\
\hline 21 & & M-KSF & $25 \%$ \\
\hline 22 & \multirow{3}{*}{41} & CAN & $31 \%$ \\
\hline 23 & & M-KSF & $52 \%$ \\
\hline 24 & & M-K10 & $46 \%$ \\
\hline 25 & \multirow{2}{*}{$4 \mathrm{~m}$} & CAN & $35 \%$ \\
\hline 26 & & M-KSF & $6 \%$ \\
\hline 27 & \multirow{2}{*}{$4 n$} & CAN & $43 \%$ \\
\hline 28 & & M-KSF & $32 \%$ \\
\hline
\end{tabular}

Abbreviations: $\mathrm{CAN}=$ ceric ammonium nitrate; $\mathrm{M}-\mathrm{KSF}=$ Montmorillonite KSF; M-K10 = Montmorillonite K10.

and 53). The Povarov reactions of the aliphatic aldehyde $(S)$ 4-Methylhexanal (4-MeHexCHO, 2f) were an exception, because they could provide a product with both catalysts (Entries 45-47, Products 5i-j).

Although there was a significant progress in the optimization efforts, and we wanted to move forward towards the target compounds described in Figure 2 and Scheme 1, we encountered a major problem in the process. We noticed that a big part of the products were lost in the purification step as described in Entries 29,40,43 and 50 (Table 3, Products $\mathbf{5 a}, \mathbf{f}, \mathbf{g}, \mathbf{l})$. Moreover, we noticed that many recovered pure products decomposed within few hours to form black tars. For instance, the product 51 (Entry 50) was collected in $96 \%$ overall purity (diastereomeric mixture of two peaks) (Figure 3(a)). We found that the purity of $\mathbf{5 l}$ decreases quickly within a few hours with concomitant formation of uncharacterized decomposition products (Figure 3(b)). The LC/MS peak of 51 completely disappeared after 24 hours of storage at room temperature (Figure 3(c)). It is worthy of hinting that storage under inert air and/or low temperature elongated the decomposition time, but the compounds quickly decompose before biological screening is completed or does another reaction towards the target compounds. Therefore, among all compounds listed above, only four compounds were relatively stable upon storage (4c, 4f, $4 \mathrm{~m}$, and $\mathbf{5 f}$ ). Two of them made of the aliphatic 1-butanal (4f and 5f), one from benzaldehyde (4c), and one from phenyl glyoxal (4m). One product was from the pyridyl amine building block (5f), and three are from aniline (4c, $4 \mathbf{f}$ and $\mathbf{4 m}$ ). The product $5 \mathbf{a}$ is one of the classic examples of Povarov chemistry that was used as positive reference in literature [26].

To conclude this chemistry investigation, our finding was that Povarov chemistry is a good tool in drug discovery that aniline or some substituted anilines are fine, but pyridine derivatives are not suitable. Aromatic aldehydes gave better yields than aliphatic aldehydes. The biggest downside of this chemistry is that either THQ or its aza analogue THN is not stable, and some have a very short shelf life.

2.7. Binding Assay of Compounds $\mathbf{4 c}, \mathbf{4 f}, \mathbf{4 m}$, and $\mathbf{5} \boldsymbol{f}$ with $\mathrm{HCV}$ NS3 Enzyme. The protocol set previously by our research group to attest any compound has NS3 inhibition activities by binding to the NS4A binding site depended on first verifying that the compound has a significant affinity towards the NS3. If it passed this initial test, a competition assay with labeled NS4A would determine how potent the compound prevents the viral NS4A from binding to the NS3. A final in vitro test would investigate if compounds with confirmed high affinity inhibited NS3 by forming inactive complex [9, 10]. Accordingly, the four compounds 4c, 4f, $\mathbf{4 m}$, and $\mathbf{5 f}$ were tested for their binding affinity towards NS3 using the label-free Differential Scanning Light Scattering technique (DSLS). This technique assesses the protein's thermal stability in terms of the formation of aggregates 
TABLE 3: THQ and THN derivatives preparation.

\begin{tabular}{|c|c|c|c|c|c|c|}
\hline Entry & Product no. & Amine & Aldehyde & Alkene & Catalyst & Product \%* \\
\hline 29 & \multirow[t]{2}{*}{$5 a$} & \multirow[t]{2}{*}{$1 b$} & \multirow[t]{2}{*}{$\mathrm{PhCHO}(\mathbf{2 a})$} & \multirow[t]{2}{*}{$\mathrm{DHP}(\mathbf{3 b})$} & CAN & $\begin{array}{c}43 \% \\
8 \% \text { (isolated) }\end{array}$ \\
\hline 30 & & & & & M-KSF & ND \\
\hline 31 & \multirow{2}{*}{$5 b$} & \multirow{2}{*}{$1 b$} & \multirow{2}{*}{ EtGlx (2d) } & \multirow{2}{*}{$\operatorname{BVE}(\mathbf{3 d})$} & CAN & $32 \%$ \\
\hline 32 & & & & & M-KSF & $25 \%$ \\
\hline 33 & \multirow{3}{*}{$5 c$} & \multirow{3}{*}{$1 b$} & \multirow{3}{*}{ Furfural (2c) } & \multirow{2}{*}{$\operatorname{DHF}(3 \mathrm{c})$} & CAN & $23 \%$ \\
\hline 34 & & & & & M-KSF & $17 \%$ \\
\hline 35 & & & & & CAN & ND \\
\hline 36 & \multirow{3}{*}{$5 d$} & \multirow{3}{*}{ 1c } & \multirow{3}{*}{$\mathrm{PhCHO}(\mathbf{2 a})$} & \multirow{3}{*}{ DHP (3b) } & M-KSF & $\mathrm{ND}$ \\
\hline 37 & & & & & CAN $(10 x)^{\S}$ & ND \\
\hline 38 & & & & & M-KSF $(10 x)^{\S}$ & ND \\
\hline 39 & $5 e$ & $1 c$ & Furfural (2c) & DHP (3b) & CAN & ND \\
\hline 40 & \multirow{3}{*}{$5 f$} & \multirow{3}{*}{$1 c$} & \multirow{3}{*}{ 1-Butanal (2b) } & \multirow{3}{*}{$\operatorname{EVE}(\mathbf{3 a})$} & CAN & $\begin{array}{c}29 \% \\
7 \% \text { (isolated) }\end{array}$ \\
\hline 41 & & & & & CAN $(10 x)^{\S}$ & $\begin{array}{l}\text { ND } \\
\text { NDolated) }\end{array}$ \\
\hline 42 & & & & & M-KSF $(10 x)^{\S}$ & ND \\
\hline 43 & $5 g$ & $1 \mathrm{c}$ & Furfural (2c) & $\operatorname{BVE}(\mathbf{3 d})$ & CAN & $\begin{array}{c}33 \% \\
8 \% \text { (isolated) }\end{array}$ \\
\hline 44 & $5 h$ & $1 \mathrm{c}$ & Furfural (2c) & $\mathrm{DHF}(3 \mathrm{c})$ & CAN & $17 \%$ \\
\hline 45 & \multirow{2}{*}{$5 \mathbf{i}$} & \multirow{2}{*}{$1 \mathrm{c}$} & \multirow{2}{*}{ 4-MeHexCHO (2f) } & \multirow{2}{*}{$\operatorname{BVE}(\mathbf{3 d})$} & CAN $(10 x)^{\S}$ & $22 \%$ \\
\hline 46 & & & & & CAN & $30 \%$ \\
\hline 47 & $5 \mathbf{j}$ & 1c & 4-MeHexCHO (2f) & $\mathrm{DHF}(3 \mathrm{c})$ & M-KSF & $3 \%$ \\
\hline 48 & \multirow{2}{*}{$5 \mathrm{k}$} & \multirow{2}{*}{$1 \mathrm{c}$} & \multirow{2}{*}{ PyrCHO (2g) } & \multirow{2}{*}{$\operatorname{DHF}(3 \mathrm{c})$} & CAN & $64 \%$ \\
\hline 49 & & & & & M-KSF & ND \\
\hline 50 & \multirow[t]{2}{*}{51} & \multirow[t]{2}{*}{ 1c } & \multirow[t]{2}{*}{ PyrCHO (2g) } & \multirow[t]{2}{*}{ DHP (3b) } & CAN & $\begin{array}{c}67 \% \\
32 \% \text { (isolated) }\end{array}$ \\
\hline 51 & & & & & M-KSF & ND \\
\hline 52 & \multirow{2}{*}{$5 \mathrm{~m}$} & $1 \mathrm{c}$ & PyrCHO (2o) & $\operatorname{BVF}(\mathbf{3 d})$ & CAN & $58 \%$ \\
\hline 53 & & Ic & PyrCHO (2g) & $B \vee E(3 d)$ & M-KSF & $\mathrm{ND}$ \\
\hline
\end{tabular}

$\mathrm{PhCHO}=$ Benzaldehyde; EGlx = Ethyl glyoxylate; 4 -MeHexCHO = (S)-4-methylhexanal; PyrCHO=2-pyridinecarbaldehyde; EVE=Ethyl vinyl ether; $\mathrm{DHP}=3,4$-Dihyro-2H-pyran; DHF = 2,3-Dihydrofuran; BVE = Benzyl vinyl ether. ${ }^{*}$ Product percentages shown are for LCMS analysis in crude mixture unless mentioned between parentheses. ${ }^{\S}$ The catalyst was used in 10-fold amount larger than what was mentioned in the section Experiment.

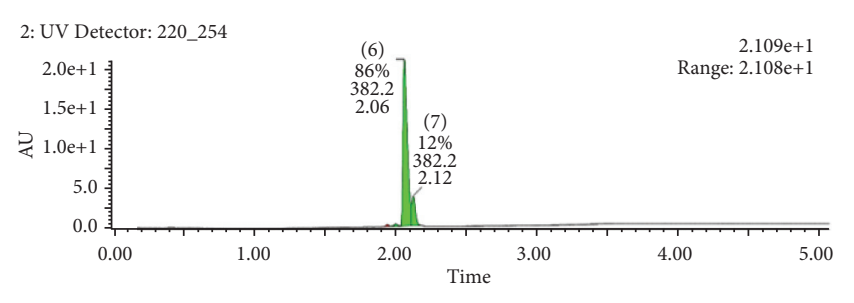

(a)

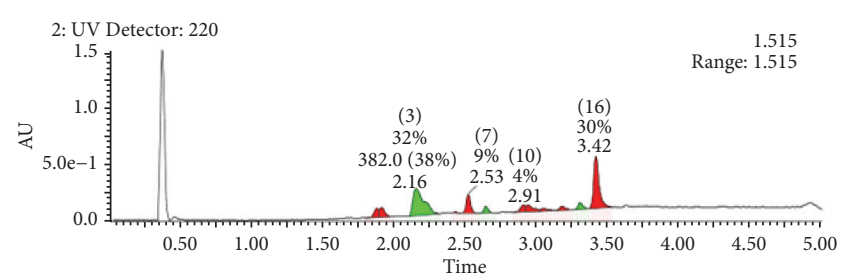

(b)

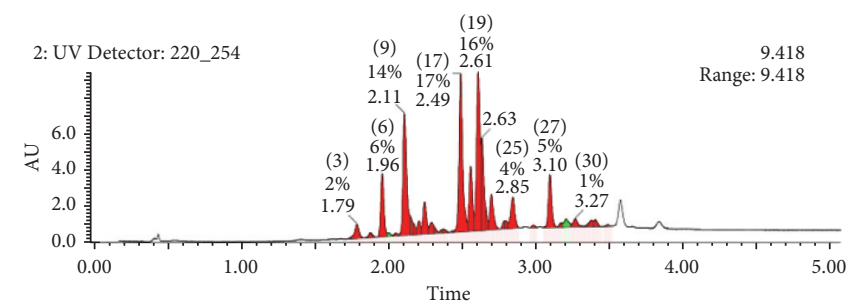

(c)

FIGURE 3: Stability study of tert-Butyl (5-(Pyridin-2-yl)-3,4,4a,5,6,10b-hexahydro-2H-pyrano[3,2-c] [1, 7]naphthyridin-9-yl)carbamate (5l), Entry 50. (a) Pure la right after HPLC purification. (b) LC/MS after 7 hours are showing complete decomposition of one isomer $(\mathrm{Rt}=2.06)$ while the isomer at $\mathrm{Rt}=2.16 \mathrm{~min}$ peak is detected. (c) LC/MS after 24 hours showed disappearance of both peaks of the compound.

upon increasing the temperature gradually from $25^{\circ} \mathrm{C}$ to $90^{\circ} \mathrm{C}$ [27]. When the target protein binds a ligand, the aggregation temperature $\left(T_{\text {agg }}\right)$ increases proportionally to the binding potency [28]. We performed this binding assay to measure the change in the aggregation temperature $\left(\Delta T_{\mathrm{agg}}\right)$ upon mixing test compounds with NS3 and compare them 
TABLE 4: Results of DSLS stability test.

\begin{tabular}{lcccccc}
\hline & & \multicolumn{3}{c}{$T_{\text {agg }}\left({ }^{\circ} \mathrm{C}\right)$} & & \\
& $4 \mathrm{c}+\mathrm{NS3}$ & $4 \mathrm{f}+\mathrm{NS3}$ & $4 \mathrm{~m}+\mathrm{NS3}$ & $5 \mathrm{f}+\mathrm{NS3}$ & 453 & $\mathrm{NS3}+\mathrm{NS} 4 \mathrm{~A}$ \\
\hline Exp1 & 45.84 & 44.84 & 45.98 & 45.82 & 43.48 & 45.69 \\
Exp2 & 45.73 & 44.92 & 46.06 & 45.49 & 45.59 & 48.12 \\
Exp3 & 45.64 & 44.80 & 45.96 & 45.59 & 45.59 & 47.43 \\
Exp4 & 45.8 & 45.17 & 46.19 & 45.66 & 45.59 & 47.8 \\
Average $T_{\text {agg }}$ & 45.75 & 44.93 & 46.05 & 0.146 & 0.086 & 0.435 \\
St. Dev. & 0.088 & 0.166 & 0.104 & 0.07 & 2.03 \\
$\Delta T_{\text {agg }}$ & 0.16 & -0.66 & 0.46 & & \\
\hline
\end{tabular}

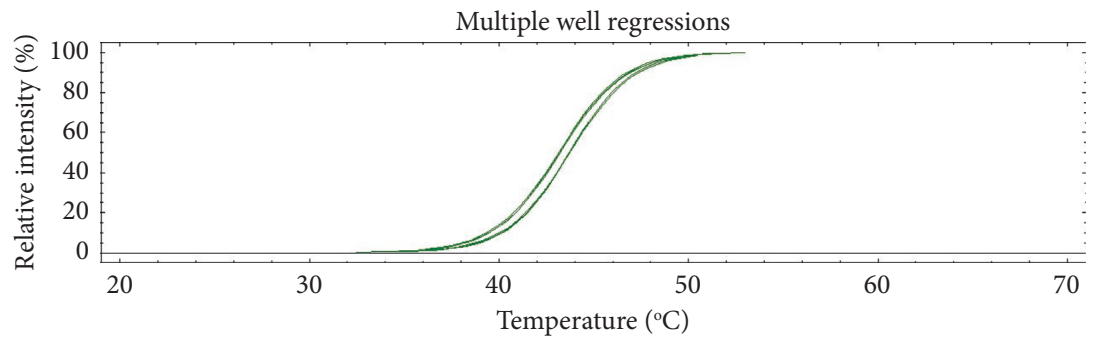

(a)

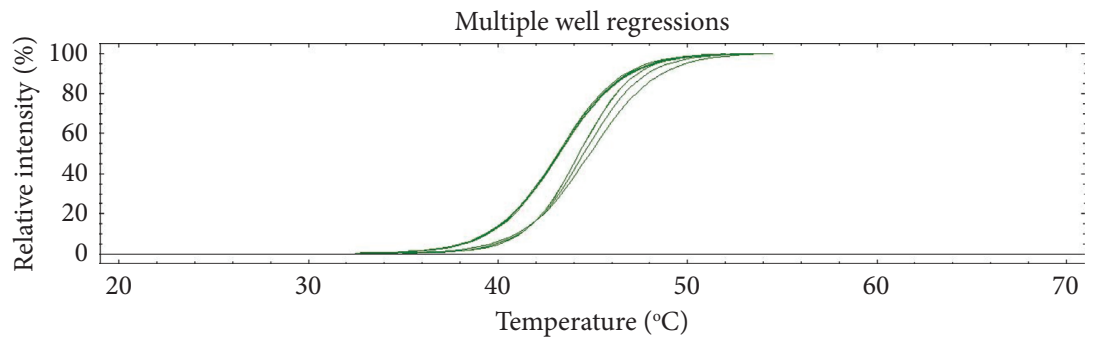

(b)

FIgURE 4: Changes in the aggregation temperature $\left(T_{\text {agg }}\right)$ in DSLS protein thermal stability assay $\left(25-85^{\circ} \mathrm{C}\right)$. (a) Compound $4 \mathrm{~m}$ mixed with NS3 (right plots) compared to NS3 alone (left plots). (b) Positive reference NS4A mixed with NS3 (right plots) compared to NS3 (left plots).

to the viral NS4A $21^{\prime}-34^{\prime}$ (Table 4). Comparing the $\Delta T_{\text {agg }}$ revealed that only compound $4 \mathrm{~m}$ showed a weak affinity to the NS3 (22.6\% of NS4A) (Figure 4). The other three compounds had nearly no affinity to the NS3. Compound $4 \mathrm{f}$ caused a drop in the thermal stability of the protein. It was not surprising that these compounds did not give any significant stability, because their structures had low similarity to the designed but failed compounds (Figure 2 and Scheme 1). The low affinity of the tested compounds was discouraging to pursue the biological screenings in the preset protocol. It is interesting to notice that the only compound that increased NS3 thermal stability was the 2-acyl analogue $4 \mathbf{m}\left(\Delta T_{\mathrm{agg}}=25 \%\right.$ of the NS4A $)$, indicating the significance of the oxo group to the binding.

\section{Conclusions}

The robustness of the Povarov reaction helped the synthesis of hundreds of medicinally relevant compounds [29]. Our finding is that the compounds produced by this reaction had some limits in diversity. For instance, in our study, diversifying the 1,2,3,4-tetrahydroquinoline with 2-acyl, 4-oxo or 7 -aza groups could not be achieved due to low yields and/or stability issues of the products. We recommend that our study be a guide for researchers before they decide to employ Povarov reaction in their screening libraries with a similar pattern of substituents.

\section{Experiment}

\subsection{Chemical Synthesis}

4.1.1. General Conditions. Solvents and reagents were purchased from Sigma-Aldrich (USA), VWR (USA), or Alfa Aesar (UK). When needed, solvents were dried according to the procedures described in the literature. Unless otherwise stated, the reactions were performed under an inert atmosphere of nitrogen. Microwave (MW) reactions were performed using Milestone StartSynth ${ }^{\text {тм }}$ reactor (Milestone Inc., Italy). Melting points (mp) were determined in open capillary tubes using electrothermal apparatus (Stuart, UK) and are uncorrected. NMR results were recorded on Bruker DPX-300 MHz (Bruker, Switzerland). HPLC-MS was performed on a Waters 2695/ZQ MSD, including a C18 column and a diode-array UV detector (Waters Inc., Milford, MA). The mobile phase (containing $0.01 \mathrm{M}$ ammonium acetate) was a gradient starting from $20 \%$ acetonitrile/ $80 \%$ water to $80 \%$ acetonitrile/20\% water. Purities are reported according 
to the percentage of peak areas at wavelength $254 \mathrm{~nm}$. According to LC-MS analyses, all compounds in this study were confirmed to have $95 \%$ purity or higher. Infrared spectra were recorded on a Thermo Scientific Nicolet iS10 Fourier transform (FT)-IR Spectrometer. In this report, we only listed the important IR stretching bands, including $\mathrm{NH}$, $\mathrm{OH}, \mathrm{CH}, \mathrm{C}=\mathrm{O}, \mathrm{C}=\mathrm{N}$, and/or $\mathrm{C}=\mathrm{C}$. In FT-IR, all samples were measured neat.

4.1.2. General Procedure for Povarov Reaction. To a stirred solution of the appropriate arylamine derivative 1a-c $(1 \mathrm{mmol})$, vinyl ether $(4.53 \mathrm{mmol})$ and the corresponding aldehyde $(4.53 \mathrm{mmol})$ in acetonitrile $(15 \mathrm{~mL})$ were added CAN $(82.78 \mathrm{mg}, 0.15 \mu \mathrm{mol})$. The mixture was stirred at room temperature overnight. The mixture was then extracted with dichloromethane $(2 \times 20 \mathrm{~mL})$, and the extract was washed with water and brine and then dried (anhydrous $\mathrm{Na}_{2} \mathrm{SO}_{4}$ ). Purification was achieved by column chromatography (Gradient, hexane 100\% to Hexane/Ethyl acetate 9:1). The previously reported compound $4 \mathbf{c}$ [26] was found identical to that in the literature; however, the ${ }^{1} \mathrm{H}$ NMR spectrum indicated that the compound $4 \mathrm{c}$ is a mixture of $58.8 \%$ trans isomer [(3aS,4R,9bS)-4-phenyl-2,3,3a,4,5,9b-hexahydrofuro $[3,2-c]$ quinoline]; and $42.2 \%$ cis isomer [ $(3 \mathrm{a} S, 4 S, 9 \mathrm{~b} S)-4$ phenyl-2,3,3a,4,5,9b-hexahydrofuro [3,2-c] quinoline.

(1) 4-Ethoxy-2-(n-propyl)-1,2,3,4-tetrahydroquinoline (4f). This compound $\mathbf{4 f}$ was collected as nonsolidified residue to be a mixture of approx. $75 \%$ trans and $25 \%$ cis according to ${ }^{1} \mathrm{H}$ NMR integrations.

${ }^{1} \mathrm{H}$ NMR, trans isomer signals only: $(300 \mathrm{MHz}$, DMSO- $\left.d_{6}\right) \delta$ ppm: $0.9\left(\mathrm{t}, J=6.99,3 \mathrm{H}, 2-\mathrm{CH}_{2}-\mathrm{CH}_{2}-\mathrm{CH}_{3}\right)$ $1.17\left(\mathrm{t}, J=6.99 \mathrm{~Hz}, 3 \mathrm{H}, 4-\mathrm{O}-\mathrm{CH}_{2}-\mathrm{CH}_{3}\right) 1.31-1.55(\mathrm{~m}, 5 \mathrm{H}$, $\left.2-\mathrm{CH}_{2}-\mathrm{CH}_{2}-\mathrm{CH}_{3} \& 3-\mathrm{CH}_{\mathrm{a}}\right) 2.18(\mathrm{~d}$ of $\mathrm{m}, J=12.84 \mathrm{~Hz}, 1 \mathrm{H}$, $\left.3-\mathrm{CH}_{\mathrm{b}}\right) 3.28$ (br. s., $\left.1 \mathrm{H}, 2-\mathrm{CH}\right) 3.44-3.57(\mathrm{~m}, 1 \mathrm{H}, 4-$ $\left.\mathrm{O}-\mathrm{CH}_{\mathrm{a}} \mathrm{H}_{\mathrm{b}}-\mathrm{CH}_{3}\right) 3.66(\mathrm{dd}, J=9.25,6.99 \mathrm{~Hz}, 1 \mathrm{H}, 4-\mathrm{O}-$ $\left.\mathrm{CH}_{\mathrm{a}} \mathrm{H}_{\mathrm{b}}-\mathrm{CH}_{3}\right) 4.52(\mathrm{dd}, J=9.82,5.29 \mathrm{~Hz}, 1 \mathrm{H}, 4-\mathrm{CH}) 5.50(\mathrm{~s}, 1$ $\mathrm{H}, 1-\mathrm{NH}) 6.41-6.53(\mathrm{~m}, 2 \mathrm{H}, 6-\mathrm{CH} \& 7-\mathrm{CH}) 6.89(\mathrm{t}$, $J=7.55 \mathrm{~Hz}, 1 \mathrm{H}, 5-\mathrm{CH}) 7.11(\mathrm{~d}, J=7.18 \mathrm{~Hz}, 1 \mathrm{H}, 8-\mathrm{CH})$. LC-MS (ESI), RT $=1.34 \mathrm{~min}, \mathrm{~m} / z 220.3[\mathrm{M}+\mathrm{H}]^{+}, \mathrm{m} / z 178.3$ [M + 1 - EtO], 86.0\% (220-254 nm).

(2) $(3,4,4 a, 5,6,10 b$-hexahydro-2H-pyrano [3,2-c]quinolin-5-yl) (phenyl)methanone (4m). The compound $4 \mathbf{m}$ was isolated as nonsolidified residue and found to be $>95 \%$ trans isomer according to ${ }^{1} \mathrm{H}$ NMR integrations.

${ }^{1} \mathrm{H}$ NMR $\left(300 \mathrm{MHz}\right.$, DMSO- $\left.d_{6}\right) \delta$ ppm: $0.99(\mathrm{~d}$, $\left.J=12.84 \mathrm{~Hz}, 1 \mathrm{H}, 4-\mathrm{CH}_{\mathrm{a}} \mathrm{H}_{\mathrm{b}}\right) 1.14-1.40\left(\mathrm{~m}, 3 \mathrm{H}, 4-\mathrm{CH}_{\mathrm{a}} \mathrm{H}_{\mathrm{b}}\right)$ $2.29\left(\mathrm{~d}, J=6.04 \mathrm{~Hz}, 1 \mathrm{H}, 5-\mathrm{CH}_{2}\right) 3.11-3.24(\mathrm{~m}, 1 \mathrm{H}, 4 \mathrm{a}-\mathrm{CH})$ $3.42\left(\mathrm{~d}, J=10.95 \mathrm{~Hz}, 1 \mathrm{H}, 2-\mathrm{CH}_{\mathrm{a}}\right) 5.28-5.39\left(\mathrm{~m}, 2 \mathrm{H}, 2-\mathrm{CH}_{\mathrm{b}}\right.$ \& $5-\mathrm{CH}) 5.71(\mathrm{~s}, 1 \mathrm{H}, 6-\mathrm{NH}) 6.62(\mathrm{t}, J=7.37 \mathrm{~Hz}, 1 \mathrm{H}, 9-\mathrm{CH})$ $6.79(\mathrm{~d}, J=7.93 \mathrm{~Hz}, 1 \mathrm{H}, 9-\mathrm{CH}) 6.99(\mathrm{t}, J=7.18 \mathrm{~Hz}, 1 \mathrm{H}$, $8-\mathrm{CH}) 7.16(\mathrm{~d}, J=7.93 \mathrm{~Hz}, 1 \mathrm{H}, 10-\mathrm{CH}) 7.58(\mathrm{t}, J=7.55 \mathrm{~Hz}, 2$ $\left.\mathrm{H}, 3^{\prime}, 5^{\prime}-\mathrm{CH}\right) 7.70\left(\mathrm{t}, J=7.36 \mathrm{~Hz}, 1 \mathrm{H}, 4^{\prime}-\mathrm{CH}\right) 7.98-8.08(\mathrm{~m}, 2$ $\mathrm{H}, 2^{\prime}, 6^{\prime}-\mathrm{CH}$ ). LC-MS (ESI), RT $=1.29 \mathrm{~min}, \mathrm{~m} / z 294.4[\mathrm{M}+$ $\mathrm{H}]^{+}, 95.0 \%(220-254 \mathrm{~nm})$.

(3) tert-Butyl (4-ethoxy-2-propyl-1,2,3,4-tetrahydro1,7-naphthyridin-6-yl)carbamate (5f). The compound $\mathbf{5 f}$ was isolated as nonsolidified residue and found to be $>90 \%$ trans isomer according to ${ }^{1} \mathrm{H}$ NMR integrations.
${ }^{1} \mathrm{H} \quad \mathrm{NMR} \quad\left(500 \mathrm{MHz}, \quad\right.$ DMSO-d $\left.\mathrm{d}_{6}\right) \quad \delta \quad \mathrm{ppm}: \quad 0.89$ $\left(\mathrm{t}, J=7.09 \mathrm{~Hz}, 3 \mathrm{H}, 2-\mathrm{CH}_{2}-\mathrm{CH}_{2}-\mathrm{CH}_{3}\right), 1.10(\mathrm{t}, J=6.94 \mathrm{~Hz}, 3 \mathrm{H}$, 4-O- $\mathrm{CH}_{2}-\mathrm{CH}_{3}$ ), $1.28-1.40\left(\mathrm{~m}, 2 \mathrm{H}, 2-\mathrm{CH}_{2}-\mathrm{CH}_{2}-\mathrm{CH}_{3}\right), 1.43$ (s, 9H, 6-NH-CO-C $\left.\left(\mathrm{CH}_{3}\right)_{3}\right), 1.49-1.55\left(\mathrm{~m}, 2 \mathrm{H}, 2-\mathrm{CH}_{2}-\mathrm{CH}_{2}-\right.$ $\left.\mathrm{CH}_{3}\right)$, 3.61-3.66 (m, $\left.1 \mathrm{H}, 4-\mathrm{O}-\mathrm{CH}_{\mathrm{a}} \mathrm{H}_{\mathrm{b}}-\mathrm{CH}_{3}\right), 3.84-3.91(\mathrm{~m}$, $\left.1 \mathrm{H}, 4-\mathrm{O}-\mathrm{CH}_{\mathrm{a}} \mathrm{H}_{\mathrm{b}}-\mathrm{CH}_{3}\right), 4.37(\mathrm{t}, J=6.78 \mathrm{~Hz}, 1 \mathrm{H}, 4-\mathrm{CH}), 5.54$ (s, $1 \mathrm{H}, 1-\mathrm{NH}), 6.90(\mathrm{~d}, J=8.83 \mathrm{~Hz}, 1 \mathrm{H}, 5-\mathrm{CH}), 7.31(\mathrm{~d}$, $J=8.83 \mathrm{~Hz}, 1 \mathrm{H}, 8-\mathrm{CH}), 9.03$ (br. s., $\left.1 \mathrm{H}, 6-\mathrm{NH}-\mathrm{CO}-\mathrm{C}\left(\mathrm{CH}_{3}\right)_{3}\right)$. LC-MS (ESI), RT $=2.84 \mathrm{~min}, \mathrm{~m} / z 336.4[\mathrm{M}+\mathrm{H}]^{+}, 92.9 \%$ (220-254 nm).

4.2. Biological Screening. All reagents used in the biological screenings were purchased from Sigma-Aldrich (UK) in molecular biology grade unless stated otherwise.

4.2.1. NS3 Protein. (1) NS3 Constructs. A synthetic gene coding for the HCV NS3 domain of genotype 4a, the most abundant HCV in Saudi Arabia and Egypt [30], was synthesized by GenScript (Hong Kong), and the nucleotide sequence was optimized for $E$. coli codon usage. The synthetic gene was cloned as a NdeI-BamHI fragment into the expression vector pET-3a Novagen ${ }^{\circledR}$. The obtained construct was sequenced to confirm that we have the right clone and the gene is in the correct frame.

\section{(2) NS3 Protein Information. Accession GU085486.1}

HCV genotype $4 \mathrm{a}$ (The most common genotype in Saudi Arabia) [31]

NS3 from 4 to 182 aa (L/E, F/E, I/Q, V/E, L/Q, C/S) NS4A 632 to 685 aa $(i / n)$

G svvivgrvnl sgdtayaqqt rgeestqets qtgrdtnenc gevqvistat qsflgtavng vmwtvyhgag sktisgpkgp vnqmytnvdq dlvgwpsppg vksltpctcg asdlylvtrh advvpvrrrg dtrgallspr pistlkgssg gpllcpmgha aglfraavst rgvakavdfv pveslett mrsp

NS4A/NS3 Fusion protein expression in pET-28a

NS3 protease domain 1-181 aa $+\mathrm{N}$-terminal $\mathrm{T} 7$ tag and C-terminal His tag

M ASMTGGQQMG apitayaqqt rglfstivts ltgrdtnenc gevqvistat qsflgtavng vmwtvyhgag sktisgpkgp vnqmytnvdq dlvgwpsppg vksltpctcg asdlylvtrh advvpvrrrg dtrgallspr pistlkgssg gpllcpmgha aglfraavct rgvakavdfv pveslettmr sGSHHHHHH

Expression in pET-3a

(3) Protein Expression. The sequence of NS3 domain for genotype 4A was expressed in E. coli Rosette (DE3) pLysS according to standard protocol [11]. Therefore, a synthetic gene for the NS3 domain was subcloned in the expression vector pET-3a. In the process, a $100 \mathrm{~mL}$ bacterial culture in Luria Broth medium grew overnight at $37^{\circ} \mathrm{C}$ and used for inoculation of $10 \mathrm{~L} \mathrm{LB}$ in a 14-liter fermenter flask (New Brunswick Scientific Co., CT, USA). The media were supplemented with ampicillin $50 \mu \mathrm{g} / \mathrm{mL}$. The culture grew until the $\mathrm{OD}_{600}$ reached $0.5-0.6$, then it was cooled to $25^{\circ} \mathrm{C}$, and 
$1 \mathrm{mM}$ IPTG was added. Expression was followed overnight, and then cells were harvested.

(4) Protein Purification. The produced protein was purified using equilibrated Ni-NTA beads, and the poly-histidine tag was not removed. In the process, cells were resuspended $(1 \mathrm{~g} /$ $5 \mathrm{~mL}$ ) in buffer ( $50 \mathrm{mM}$ HEPES, $0.3 \mathrm{M} \mathrm{NaCl}, 10 \%$ glycerol, $2 \mathrm{mM} \beta$-mercaptoethanol, $\mathrm{pH} 8$ ). Lysozymes were added $(1 \mathrm{mg} / \mathrm{mL})$ followed by a protease inhibitor cocktail tablet, and the suspension was sonicated. Cell lysate was centrifuged to collect the clear supernatant that contained the desired NS3 protein. The protein was purified using preequilibrated Ni-NTA beads (Qiagen, USA). Beads were washed with buffer (50 mM HEPES, $0.3 \mathrm{M} \mathrm{NaCl}, 10 \%$ glycerol, $2 \mathrm{mM} \beta$-mercaptoethanol, $20 \mathrm{mM}$ imidazole, $\mathrm{pH} 8$ ) and eluted with another buffer (50 mM HEPES, $0.3 \mathrm{M} \mathrm{NaCl}$, $10 \%$ glycerol, $2 \mathrm{mM} \beta$-mercaptoethanol, $350 \mathrm{mM}$ imidazole, $\mathrm{pH} 8)$. Fractions were collected and concentrated using Amicon Ultra-4 3000 MWCO centrifugal device (Millipore, Germany). Protein purity after the Ni-affinity purification step was not less than $70 \%$. The purity, as estimated by SDSPAGE, was sufficient to perform all investigations of this study, and the protein was stable for several hours at test conditions [30]. The concentration of NS3 in the final concentrate was measured using Nanodrop ${ }^{\mathrm{TM}}$ nanoscale spectrophotometer.

When needed, further purification of the protein was accomplished on Superdex 75 16/90 column (GE Healthcare, USA) equilibrated in $20 \mathrm{mM}$ HEPES, $10 \mathrm{mM}$ DDT, $200 \mathrm{mM}$ $\mathrm{NaCl}, \mathrm{pH} 7.6$ run at a rate of $1 \mathrm{~mL} / \mathrm{min}$ followed by SDSPAGE for purity estimation.

4.2.2. NS4A. The cofactor NS4A and the fluorescent fluorescein isothiocyanate NS4A (FITC-NS4A) were purchased from GenScript (Hong Kong). NS4A structure was identical to that of HCV genotype $\mathbf{4 a}$, with two lysine residues added at both the N- and C-termini. Thus, the structure of NS4A used in this study was LL-G ${ }_{21}$ SVVIVGRIVLSG $_{33}$-LL.

We studied the binding of NS4A and its mutants with NS3 by DSLS using Stargazer-2 ${ }^{\mathrm{TM}}$ (Harbinger Biotechnology and Engineering Corporation, Toronto, Canada). This method assesses protein stability by monitoring aggregate formation at controlled, gradually elevated temperatures [27]. NS3 domain stability upon binding to NS4A was measured by monitoring denatured protein aggregation upon increasing temperature from 25 to $85^{\circ} \mathrm{C}\left(0.5^{\circ} \mathrm{C}\right.$ increments) at $600 \mathrm{~nm}$.

4.2.3. DSLS Binding Test. NS3 domain $(15 \mu \mathrm{M})$ alone or mixed with the equimolar equivalent of tested MOC derivative was added to a binding buffer (20 mM HEPES, $10 \mathrm{mM}$ DTT, $200 \mathrm{mM} \mathrm{NaCl}, \mathrm{pH}$ 7.6) to a final volume $100 \mu \mathrm{L}$. The mixture was incubated at room temperature with gentle shaking for $2 \mathrm{~h}$. Afterward, $10 \mu \mathrm{L}$ of the mixture was transferred into a clear bottomed Nunc 384-well plate and covered with $10 \mu \mathrm{L}$ paraffin oil to minimize evaporation. Protein aggregation was monitored by tracking the change in scattered light that was detected by a Charged Coupled
Device (CCD) camera. Snapshot images of the plate were taken every $0.5^{\circ} \mathrm{C}$. The pixel intensities in a preselected region of each well were integrated using image analysis software to generate a value representative of the total amount of scattered light in that region. These intensities were then plotted against temperature for each sample well and fitted to obtain the aggregation temperature $\left(T_{\text {agg }}\right)$. Aggregation was monitored and analyzed to assess the effect of NS4A and its synthetic analogues on the stability of the NS3 as an indicator of binding. Each experiment was repeated 3 times. Statistical analysis was performed using GraphPad Prism v. 8.0 ${ }^{\circledR}$ and Instat ${ }^{\circledR}$ software.

\subsection{Molecular Modeling}

4.3.1. Hardware and Software. Molecular modeling experiments were performed using SYBYL-X package v. 2.0 (with a license to the Faculty of Pharmacy, King Abdulaziz University) installed on Common Desktop run on Windows 7 operating system and equipped with Samsung SyncMaster 2233RZ $120 \mathrm{~Hz}$ LCD Display ${ }^{\mathrm{TM}}$ (3D ready) and Nvidia GeForce 3D Vision Glasses $\mathrm{Kit}^{\mathrm{TM}}$. The graphics of images were generated using PyMOL free software (https://pymol. $\operatorname{org} / 2 /)$.

4.3.2. Preparation of the Protein. The 3-dimensional structure of NS3/4A protease [32] was downloaded from the Protein Data Bank (rcsb.org, Code: 1NS3), and its dimer structure was simplified to a monomer and optimized using Biopolymer $>$ Prepare Structure tools. The Pep-15 was prepared by Biopolymer $>$ Composition $>$ Mutate Structure tools.

4.3.3. Molecular Mechanics. MM was performed using Staged Minimization tools (Force Field: Amber 7 FF02, Charges: Amber) [33].

\section{Data Availability}

Spectra and biological data are available upon request by any party.

\section{Conflicts of Interest}

The authors declare no conflicts of interest.

\section{Acknowledgments}

This project was funded by the Deanship of Scientific Research (DSR), King Abdulaziz University, Jeddah, the Kingdom of Saudi Arabia, under grant number RG-20-16641. The authors, therefore, acknowledge with thanks DSR for the technical and financial support.

\section{Supplementary Materials}

The supplementary material file contains ${ }^{1} \mathrm{H}$ NMR and LC/ MS spectra of compounds $\mathbf{4 c}, \mathbf{4 f}, \mathbf{4 m}$ and $\mathbf{5 c}$. (Supplementary Materials) 


\section{References}

[1] B. R. Edlin, "Perspective: test and treat this silent killer," Nature, vol. 474, no. 7350, pp. s18-s19, 2011.

[2] C.-T. K. Tseng and G. R. Klimpel, "Binding of the hepatitis C virus envelope protein E2 to CD81 inhibits natural killer cell functions," Journal of Experimental Medicine, vol. 195, no. 1, pp. 43-50, 2002.

[3] R. B. Ray and R. Ray, "Hepatitis C virus manipulates humans as its favorite host for a long-term relationship," Hepatology, vol. 69, no. 2, pp. 889-900, 2019.

[4] S. N. B. Cashman, B. D. Marsden, and L. B. Dustin, "The humoral immune response to HCV: understanding is key to vaccine development," Frontiers in Immunology, vol. 5, p. 550, 2014.

[5] H. Li, M.-H. Huang, J.-D. Jiang, and Z.-G. Peng, "Hepatitis C: from inflammatory pathogenesis to anti-inflammatory/hepatoprotective therapy," World Journal of Gastroenterology, vol. 24, no. 47, pp. 5297-5311, 2018.

[6] A. A. Rabaan, S. H. Al-Ahmed, A. M. Bazzi et al., "Overview of hepatitis C infection, molecular biology, and new treatment," Journal of Infection and Public Health, vol. 13, no. 5, pp. 773-783, 2020.

[7] Q. Xie, J.-W. Xuan, H. Tang et al., "Hepatitis C virus cure with direct-acting antivirals: clinical, economic, societal and patient value for China," World Journal of Hepatology, vol. 11, no. 5, pp. 421-441, 2019.

[8] D. K. Li and R. T. Chung, "Overview of direct-acting antiviral drugs and drug resistance of hepatitis C virus," Methods in Molecular Biology, vol. 1911, pp. 3-32, 2019.

[9] A. M. Omar, M. A. Elfaky, S. T. Arold et al., "1H-Imidazole2,5-Dicarboxamides as NS4A peptidomimetics: identification of a new approach to inhibit HCV-NS3 protease," Biomolecules, vol. 10, no. 3, p. 479, 2020.

[10] M. E. El-Araby, A. M. Omar, S. H. Soror et al., "Synthetic bulky NS4A peptide variants bind to and inhibit HCV NS3 protease," Journal of Advanced Research, vol. 24, pp. 251-259, 2020.

[11] J. L. Kim, K. A. Morgenstern, C. Lin et al., "Crystal structure of the hepatitis C virus NS3 protease domain complexed with a synthetic NS4A cofactor peptide," Cell, vol. 87, no. 2, pp. 343-355, 1996.

[12] R. A. Love, H. E. Parge, J. A. Wickersham et al., "The crystal structure of hepatitis $\mathrm{C}$ virus NS3 proteinase reveals a trypsinlike fold and a structural zinc binding site," Cell, vol. 87, no. 2, pp. 331-342, 1996.

[13] Y. Shimizu, K. Yamaji, Y. Masuho et al., "Identification of the sequence on NS4A required for enhanced cleavage of the NS5A/5B site by hepatitis C virus NS3 protease," Journal of Virology, vol. 70, no. 1, pp. 127-132, 1996.

[14] L. Tomei, C. Failla, R. L. Vitale, E. Bianchi, and R. De Francesco, "A central hydrophobic domain of the hepatitis C virus NS4A protein is necessary and sufficient for the activation of the NS3 protease," Journal of General Virology, vol. 77, no. 5, pp. 1065-1070, 1996.

[15] P. Knochel and G. A. Molander, "Comprehensive organic synthesis, II II," 2014.

[16] M. M. Sarmah and D. Prajapati, "Aza-diels-alder reaction: an efficient approach for construction of heterocycles," Current Organic Chemistry, vol. 18, no. 12, pp. 1586-1620, 2014.

[17] J. J. Li, "Pavorov reaction," in Name Reactions: A Collection of Detailed Mechanisms and Synthetic Applications Fifth Edition, pp. 493-494, Springer International Publishing, Cham, Switzerland, 2014.
[18] J. S. Bello Forero, J. Jones Junior, and F. M. da Silva, "The Povarov reaction as a versatile strategy for the preparation of 1, 2, 3, 4-tetrahydroquinoline derivatives: an overview," Current Organic Synthesis, vol. 13, pp. 157-175, 2016.

[19] J. S. B. Forero, J. J. Junior, and F. M. d. Silva, "The Povarov reaction as a versatile strategy for the preparation of 1,2,3,4tetrahydroquinoline derivatives: an overview," Current Organic Synthesis, vol. 13, pp. 157-175, 2021.

[20] I. Muthukrishnan, V. Sridharan, and J. C. Menéndez, "Progress in the chemistry of tetrahydroquinolines," Chemical Reviews, vol. 119, no. 8, pp. 5057-5191, 2019.

[21] D. Singh, V. Kumar, C. C. Malakar, and V. Singh, "Structural diversity attributed by aza-diels-alder reaction in synthesis of diverse quinoline scaffolds," Current Organic Chemistry, vol. 23, pp. 920-958, 2021.

[22] V. Sridharan, P. A. Suryavanshi, and J. C. Menéndez, "Advances in the chemistry of tetrahydroquinolines," Chemical Reviews, vol. 111, no. 11, pp. 7157-7259, 2011.

[23] N. Isambert, M. Cruz, M. J. Arévalo, E. Gómez, and R. Lavilla, "Enol esters: versatile substrates for mannich-type multicomponent reactions," Organic Letters, vol. 9, no. 21, pp. 4199-4202, 2007.

[24] M. E. El-Araby and A. M. E. Omar, "A single-step synthesis of 1,3,4, 6-tetraaryl -5-aryliminopiperazin-2-one," Journal of Heterocyclic Chemistry, vol. 58, no. 2, pp. 442-449, 2021.

[25] T.-S. Li, Z.-H. Zhang, F. Yang, and C.-G. Fu, "Montmorillonite clay catalysis. Part 7.1 an environmentally friendly procedure for the synthesis of coumarins via pechmann condensation of phenols with ethyl acetoacetate," Journal of Chemical Research, vol. 1, pp. 38-39, 1998.

[26] J. Yu, H.-J. Jiang, Y. Zhou, S.-W. Luo, and L.-Z. Gong, "Sodium salts of anionic chiral cobalt(III) complexes as catalysts of the enantioselective Povarov reaction," Angewandte Chemie International Edition, vol. 54, no. 38, pp. 11209-11213, 2015.

[27] M. Vedadi, F. H. Niesen, A. Allali-Hassani et al., "Chemical screening methods to identify ligands that promote protein stability, protein crystallization, and structure determination," Proceedings of the National Academy of Sciences, vol. 103, no. 43, pp. 15835-15840, 2006.

[28] G. A. Senisterra, E. Markin, K. Yamazaki, R. Hui, M. Vedadi, and D. E. Awrey, "Screening for ligands using a generic and high-throughput light-scattering-based assay," Journal of Biomolecular Screening, vol. 11, no. 8, pp. 940-948, 2006.

[29] O. Ghashghaei, C. Masdeu, C. Alonso, F. Palacios, and R. Lavilla, "Recent advances of the Povarov reaction in medicinal chemistry," Drug Discovery Today: Technologies, vol. 29, pp. 71-79, 2018.

[30] M.-J. Massariol, S. Zhao, M. Marquis, D. Thibeault, and P. W. White, "Protease and helicase activities of hepatitis C virus genotype 4, 5, and 6 NS3-NS4A proteins," Biochemical and Biophysical Research Communications, vol. 391, no. 1, pp. 692-697, 2010.

[31] A. Bawazir, F. AlGusheri, H. Jradi, M. AlBalwi, and A.-G. Abdel-Gader, "Hepatitis C virus genotypes in Saudi Arabia: a future prediction and laboratory profile," Virology Journal, vol. 14, no. 1, p. 208, 2017.

[32] Y. Yan, Y. Li, S. Munshi et al., "Complex of NS3 protease and NS4A peptide of BK strain hepatitis C virus: a 2.2 A resolution structure in a hexagonal crystal form," Protein Science, vol. 7, no. 4, pp. 837-847, 1998.

[33] D. A. Case, T. E. Cheatham, T. Darden et al., "The Amber biomolecular simulation programs," Journal of Computational Chemistry, vol. 26, no. 16, pp. 1668-1688, 2005. 